\title{
Informality, Inequality and Social Reintegration in Post-War Transition
}

\author{
VESNA BOJICIC-DZELILOVIC \\ The London School of Economics and Political Science, United Kingdom
}

\begin{abstract}
This article seeks to reconceptualize the notion of informality in the post-war context in order to investigate the neglected aspect of inequality which is associated with this kind of practice. It locates the problem of widespread informality in the social transformation triggered by the war that has been sustained by the post-war elite accommodation. Inequities created by a routine resort to informal arrangements in accessing assets and resources generate mistrust at the interpersonal, inter-group and institutional levels, sharpen a sense of discrimination and social injustice, and in the end, undermine post-war social reintegration. The argument draws on observations from Bosnia-Herzegovina.
\end{abstract}

\section{Introduction}

It has become commonly understood that the rise of informal economy and of systemic corruption are the sores that are eating into the very foundations needed to support recovery from recent wars in the Western Balkans. Both represent social mechanisms of informal redistribution and both are linked to poverty, inequality, social exclusion, and to a growing sense of social injustice that the policies of post-war reconstruction have not been able to reverse (UNDP, 2011).

In the academic debates, the types of inequality linked to informality as an umbrella term for various forms of non-compliance with rules and regulations including informal economy and corruption, are rarely addressed. The analysis of inequality and social exclusion in the Western Balkans has followed in the footsteps of the mainstream scholarship on the subject (Ruggeri Laderchi \& Savastano, 2013; Stubbs, 2009; Matkovic, 2006; 
UNDP, 2007; World Bank, 2012). This is peculiar insofar as discrimination through informality operates in a transversal fashion, cutting across other categories of exclusion /inclusion as it determines access to resources and opportunities - the possession of which mitigates social exclusion.

A substantial body of scholarly and policy literature deals with the subject of informal economy and corruption in a post-war context, often including the Western Balkans, and Bosnia-Herzegovina in particular, as a case study. This scholarship provides wide-ranging perspectives on the nature of the phenomenon, its origins, and effects. This article responds to the existing approaches to the problem of informal economy and corruption in the postcommunist, post-conflict context of the Western Balkans by drawing on the insights from the regulation theory to explain their origins and account for their persistence, with specific reference to Bosnia-Herzegovina. Rather than focusing on Bosnia-Herzegovina as an in-depth case study, the primary ambition is to reframe the concepts of informality and inequality better to reflect the post-war transition context. Based on the proposed reconceptualization, the article investigates the implications of informality in terms of social justice outcomes and social reintegration as critical aspects of post-war rehabilitation.

The argument is that social transformation in the course of the 1992-1995 war, underwritten by the proliferation of informal and criminal activity involving state institutions, was a critical moment in the transformation of state/society relations and their informalization in Bosnia-Herzegovina. A notion of economic criminalization is used as a framework to bridge various strands of explanations and to demonstrate that informality is socially embedded in post-war Bosnia-Herzegovina. It was built into economic foundations of the post-war elite bargain around a three-way division of power along ethnic lines. To an important degree, the sources of ethnic elites' political and economic power remain linked to informal economic practices in which all three groups engage. The result is a discriminatory system of rule that rests on informal arrangements, and these arrangements produce an ambiguous effect in terms of social justice outcomes. To a certain degree, informality may have ameliorative effects across the society, while at the same time it bolsters the social status of those well-connected political and economic heavyweights. But the inequities that result generate mistrust at the interpersonal, inter-group, and institutional level and also sharpen a sense of discrimination and social injustice, which makes post-war social reintegration an elusive goal.

The paper is organized in three sections. The first is a selective overview of the literature on corruption and informal economy against which the concept of economic criminalization, originally developed to explain widespread informality during post-communist transition, is introduced, and is applied to a context of war and post-war transition. Drawing mainly on examples from Bosnia-Herzegovina, supplemented by relevant evidence from the broader Western Balkans context, the second section analyzes various facets of inequality associated with widespread informality, which affects 
every individual in the country, and demonstrates its destructive impact on rebuilding interpersonal and institutional trust in post-war society. The third section summarizes and concludes.

\section{Post-War Informality: An Alternative Synthesis}

Since the early 1970s, when the notion of informal economy first entered development economics discourse, the literature on the subject has proliferated. A host of terms now aim to capture the phenomenon of economic exchange outside the remit of state-sanctioned regulations (Guha-Khasnobis, Kanbur, \& Ostrom, 2006). With the institutional turn in social science, informal economy research has transgressed into several other social science disciplines. Consequently, a range of related terms operate in conjunction with the notion of informal economy, including, informal institutions, informal rules, informal structures, and informal networks, to name but a few (Meyer, 2008). These notions are employed in tandem with a conceptual arsenal designed to capture the nature of ties operating through informal, personalized arrangements such as clientelism, patronage, corruption, influence and collusion (Stefes, 2006; Upchurch, 2012). In discussions of informality as a social phenomenon and a field of academic inquiry, the above terms are commonly and quite routinely cited in an interchangeable fashion. This results, according to Ravi Kanbur (2009), in a literature that is burdened by the very imprecision indicated by the nature of the subject matter, which embraces a variety of approaches and provides no theory as such - in other words, "a mess" (p.4). ${ }^{1}$

It is useful to mention two key traditions in the study of informal economy that will prove crucial to the argument this paper develops in relation to conflict-affected countries. Studies in economic tradition generally take a definitional approach to informal economy, since their main objective is to measure its size. ${ }^{2}$ In contrast, the behavioural approaches are more concerned with the origins and types of informal economy. Common to both traditions is to consider compliance with the established judicial, regulatory and institutional frameworks regulating certain types of activities as the principal criteria by which to identify informal economy. ${ }^{3}$ The focus on rule compliance situates the origins of informal economy in the relations between the state and the economy. Consequently, in explaining the causes of noncompliant behaviour, the ultimate question for the majority of scholars is that of appropriateness of the state-sanctioned rules and their effective enforcement. The standard argument posits that informal economy develops as a response to limitations posed by rules and regulations devised and enforced by the state (De Soto, 2001). By this definition, the two "sides," namely the state and the actors who do not heed its rules, are institutionally distinct and exist in opposition to each other. This reasoning is captured by policy debates in which the discourse focuses on how to "formalize," or, how to bring informal activities and/or their protagonists into the realm of 
the formal. Such an approach is translated into a set of policies which aim to reduce and regulate state interference in the economy (World Bank, 2007). Yet simultaneously, the mainstream economics discourse is not concerned with the question of why the rules are inadequate, let alone why, beyond identifying inadequate institutional (essentially, bureaucratic) capacity as a problem, their enforcement falls short.

The supposition of the key role of the state as a rule-making and a ruleimplementing authority in the explanation of informal economy as identified in the mainstream economics tradition has been analytically upended by scholarship on post-communist transition. At the core of transition to a market economy is the reconfiguration of the role of the state and its relations with the economy so as to enable free market competition (Aslund, 1999; Gross \& Steinher, 2004). Hence, any analysis of the incidence of non-compliance with rules sanctioned by the state in the context of the post-communist transition has to factor in the transformation of the state itself. While the driving logic, rooted in the neoclassical economics tradition, of why non-compliance with rules occurs (it is because the rules are inadequate and/or poorly enforced) is maintained, the main explanations on both accounts attribute it to a mismatch between formal and informal institutions. Resorting to ingrained behavioural patterns rooted in assumed norms and traditions, which involve personalized transactions, is arguably a logical response to the upheaval of institutional transformation provoked by the state's changing role in the economic domain (Grzymala-Busse, 2010; Helmke and Levitsky, 2004; Ledeneva 2006; Meyer, 2008). The resilience of informal institutions has been identified as an important and initially neglected aspect in explaining the slow pace of transition reforms and its unpredictable patterns (Raiser, 1997). Thus economists discovered that the informal economy expanded in the early transition period to resemble more closely patterns typically seen in the developing world, that the informal economy was not easily distinguishable from the formal economy, which is characterized pointedly by a co-existence of state and non-state actors (Johnson, Kaufmann, \& Zoido-Lobaton, 2000; Simon, Kaufman, \& Shleifer, 1997). The latter insight resonated with findings from the political science tradition, which identified corruption, both in terms of its systemic nature, as well as its specific forms such as state capture, to be the hallmark of informality in the post-communist transition (Hellman, Jones \& Kaufman, 2000). Once informal economy and corruption were identified as the two foremost types of non-compliance with formal rules during the post-communist transition, various explanations of their linkage went so far as to establish that the two moved largely in the same direction (i.e. more corruption is associated with a larger informal economy). Overall, the scholarship stopped short of weaving informal economy and corruption into an integrated analytical framework to provide an explanation of widespread informality in a post-communist transition centred on the transformation of the state as the principal rule-setting authority. ${ }^{4}$ Almost a quarter of a century since the onset of transition towards liberal market democracy in the former communist world, informal economy and corruption continue to thrive, a 
testimony to the insufficient explanatory potential of the dominant approaches neither to account for their enduring nature, nor to provide guidelines for an effective policy response.

A different view of the problem of expansion in informal economy and its pervasiveness in an early post-communist transition comes from the stream of French regulation theory, which serves to conceptualize that corruption is in fact integral in the expansion of informal economy and also its transformation. By placing the transformation of the state itself at the centre of enquiry, Jacque Sapir (2006) has challenged the mainstream approaches to informal economy and its links to corruption under post-communist transition. His critique questions a narrow focus on the legal content of rules in the mainstream scholarship on informal economy, or neoclassical economics, and draws attention to the importance of social legitimacy of rules as a critical factor in explaining (non-)observation of rule-compliance. Sapir posits that rule compliance depends on whether society perceives the rule-making process and rule enforcement, which involves state institutions in charge of implementing rules, as legitimate. For the legal norms to be effectively binding, and to provide a meaningful boundary between illegal and criminal activity, both the rules and the institutions charged with their implementation require societal acceptance. Social legitimacy of rules and institutions that implement them can be undermined because of a number of reasons, including: rules being externally imposed, frequent changes in rules, incomplete rules, or compromised rule enforcement institutions. Further, all of these reasons were amplified in the context of radical transformation of the communist state, an economic regression, and a sudden impoverishment of masses across former communist countries. This complexity created a context in which rule non-compliance came to be accepted by society in general. Sapir explains how, as a consequence of the conflation of economic and political transition, the post-communist state weakened and the resort to illegal and criminal methods ${ }^{5}$ involving the agents of the state, proliferated. In the economic domain, as the formal economy shrank, outright criminal activity expanded. Most importantly, the economic space in between those two poles of "formal" (regulated economy) and criminal (operating in breach of state laws), namely the activities characterized by the use of informal, including illegal and criminal, means to produce and exchange formal (legal) goods and services expanded. When the communist countries opened their borders and began economic liberalization all types of activities, which involved a breach of rules and regulations, such as smuggling, tax evasion, and money laundering, proliferated (Feige \& Ott, 1999).

Echoing the proposition of Preston-Whyte's and Rogerson's (1991) to study informal economy as a process, Sapir calls the collusion of a shrinking formal and an expanding criminal economy, along with an increasing resort to illegal and criminal means in economic exchange by economic actors, the process of "economic criminalization," a term that depicts the pervasive nature of informality in post-communist transition at the core of which is the transformation of the state. The state's involvement in breaching the very 
rules it sets and is expected to enforce-inaptly conveyed by the standard understanding of corruption as the abuse of public office for private gain (Mungiu-Pippidi, 2011) - is instrumental in understanding the erosion of the social legitimacy of state-sanctioned rules, and why and how informality becomes a widely accepted societal practice. Socio-economic hardship and the communist legacy of rule non-compliance operate as an additional set of factors feeding "economic criminalization" dynamic.

Transposing the analytical framework of "economic criminalization" to post-conflict (and post-communist) transition ${ }^{6}$ in Bosnia-Herzegovina, in the aftermath of a war in which statehood itself was contested by the three dominant ethnic groups, provides a more appropriate lens through which to analyse types of informality, their persistence and consequences beyond their economic costs in the post-war milieu. Within the context of BosniaHerzegovina's 1992-1995 war, "economic criminalization" manifested itself in an accentuated form. The disintegration of the state through the fusion of violence, crime, and extremist politics gave birth to extreme forms of informalization in the way state, society, and markets interact. The war economy that developed was by any measure illegal and criminal (Andreas, 2004; Donais, 2005; Pugh, 2004), and included agents of the state among its key protagonists, alongside multiple other actors both local as well as regional and international (Devine \& Mathisen, 2005; ESI, 1999). This fusion erased any meaningful distinction between formal/informal economy based on legal grounds as per the standard definition of informal economy, as well as the distinction between public and private domains as the definitional axiom for corruption. The same group of actors controlled both the polity and the economy. The political and economic fragmentation of the country through the identity politics pursued by the three ethnic elites-Bosniak, Croat and Serb-enabled the groups, within their own ethnic kin constituencies, to implement strategies of legitimation which involved mobilization of resources through illegal and criminal activity (Donais, 2003; USIP, 2002). Those ranged from organized crime in arms, drugs, and people-trafficking, looting of business compounds and commercial premises, to theft and dispossession of citizens (Griffith, 1999; Newman, 2007). Not only did such practices fail to meet legal and social sanctions - the ultimate justification being that they were a necessary means to protect ethnic group interests - but they permeated the public body at large. Ordinary people, too, engaged in petty crimes, violent expropriation through ethnic cleansing often aimed at their immediate neighbours, former colleagues, or friends, or they partnered with organized crime-not to mention taking up less sinister survival activities, albeit through illegal means such as widespread selling of smuggled goods. Consequently, the social order that emerged in the aftermath of conflict had in its economic foundations a profoundly criminalized economy, in the sense that formal economy occupied a minority share of Bosnia-Herzegovina's economic space. ${ }^{7}$ Resort to informal practice was, and still is, by the conventional measures of informal economy, widespread, which arguably is one of the legacies of Bosnia's war economy. Informal economy in Bosnia- 
Herzegovina amounted to around $36.7 \%$ of GDP in 2003 and was second only to the then union of Serbia and Montenegro with 39.1\% (Schneider, 2006). Similar size of informal economy was recorded in the Former Yugoslav Republic of Macedonia (FYR Macedonia) (36.3\%) and slightly lower in Albania (35.3\%) and Croatia (35.4\%) while other sources variously estimated the size of informal economy in Kosovo between 39-53\% of GDP (Haas, 2011). The data from various sources on informal employment estimate the percentage of informal economy in the Western Balkans at around 25-35\% (ILO, 2011) and specifically in Bosnia-Herzegovina at around 30\%; using a different measure of informal employment, informal economy in BosniaHerzegovina between 2001-2004 is estimated at 42\% (Krstic \& Sanfey, 2007). A recent study of Serbia's informal economy identifies it as a multifaceted, heterogeneous, and deeply rooted phenomenon, whereby over time, the entire society in various forms was involved (FREN, 2013, p. 21). A similar assessment applies to many parts of the Western Balkan region, Bosnia-Herzegovina included, which suggests that a shared experience of wars in the region coupled with difficult post-communist transition has had a distinct impact on the patterns of informality. Various assessments of crime and organized crime show that organized crime, which flourished during the wars of former Yugoslavia's succession, remains a problem; in particular, narcotics, human trafficking, prostitution, and smuggling of various goods (Anastasijevic, 2010; UNODOC, 2008). Explanations of its persistence commonly point to the close links between the agents of the state and various criminal actors, which during the war in Bosnia-Herzegovina were symbiotic, and proved difficult to terminate in its aftermath. A similar pattern can be observed across the successor states of the former Yugoslavia, but perhaps most pronouncedly in Kosovo. The reality is, according to Donais (2003), that crime and corruption have been institutionalized as a result of a collusion of ethnic elites, criminal elements, and state officials (p. 360). Thus, informality in post-war Bosnia-Herzegovina, and one can plausibly argue Kosovo and FYR Macedonia too, does not appear to be just a transitory postwar phenomenon. Certainly, incentives to disregard formal rules have been potent during Bosnia-Herzegovina's slow and convoluted post-conflict economic transformation aggravated by political instability, which is captured in the statistics on the incidence of tax avoidance, smuggling, and corruption (Divjak \& Pugh, 2008; Transparency International, 2012). In the final analysis, the persistence of informality as a modus operandi for the post-war social order in Bosnia-Herzegovina whereby resources are mobilized through informal means, underwrites an "elite bargain" (Hesselbein, 2011) among Bosnia-Herzegovina's three ethnic groups, ${ }^{8}$ and shapes political institutions based on a three-way division of power and authority along ethnic lines. This pattern of informal resource mobilization was firmly established during the war and consolidated in its aftermath. The impressive accumulation of wealth and power among the members of ethnic elites who were prominent wartime players, and those connected to them, has continued into the post-war era, creating a system which has encouraged a reliance on informal channels to 
obtain privileged positions in accessing resources and opportunities. A tacit agreement on "the rules of the game," which is lodged in a political settlement lacking a shared vision of Bosnia-Herzegovina's statehood necessary to legitimate state-sanctioned rule, allows three ethnic elites, or "ethnocracies" in Mungiu-Pippidi's terminology (2011, p. 28), to control access to power and opportunities for wealth accumulation. The consequence is an arbitrary system of rule in which an ethnic filter is the main, although not exclusive, criterion for accessing resources and opportunities. This system of rule serves to preserve the outcomes of social transformation triggered by violence through which wealth was redistributed and society was stratified. Even though it often pales in significance against the dominant narrative of interethnic violence, the contest over the power to control resources was an integral aspect of the 1992-1995 war (Woodward, 2011) and economic criminalization through the involvement of the agents of the state, ensued. Therefore, informality, which is woven into the economic foundations of the post-war social order in Bosnia-Herzegovina, is both a structural and more pernicious phenomenon than standard scholarship on informal economy and corruption would lead us to think. It is a social order in which the sources of political and economic power are located outside formal institutional sites, and in which informal arrangements through personalized relations are instrumental in gaining access to resources and opportunities both at the elite and grass roots level. The following section outlines the main features of this system of rule characterized by widespread informality and explores its implications for equity and social justice outcomes in the process of post-war recovery in Bosnia-Herzegovina.

\section{Inequality, Trust, and Post-War Social Reintegration}

The evidence of the experience of war-affected countries worldwide proves unequivocally that post-war transition to a stable "positive peace" depends on reconstructing the relationship between state and society. In countries where varying groups engage in "competitive statebuilding" (Staniland, 2012) such as Bosnia-Herzegovina, Kosovo, and FYR Macedonia, this presents a monumental challenge, as evidenced by on-going loggerheads over acceptable political arrangements. In Bosnia-Herzegovina, nearly 20 years after the end of the 1992-1995 war, there does not appear to be "a collective vision of a shared national project" (ODI, 2012, p. 25) that would provide a glue to repair those relations and bind the Bosnian nation afresh, lending legitimacy to the nascent state. Recent research (World Bank, 2011) draws attention to the role of political leadership in guiding the process of restoration in state/society relations, and in particular, to the importance of building inclusive coalitions that would create a sense of fairness and social justice across the population (p.124). This is because exclusionary institutions undermine the trust between the state and societal groups as well as among the groups themselves (Lindeman, 2008; ODI, 2012; Putzel \& Di John, 
2012), and these institutions prevent society from dealing with its legacies of conflict. Bosnia-Herzegovina's three-way political settlement along ethnic lines institutionalizes discrimination of its people, the case in point being the infamous Sejdic-Finci case - the appeal by a Bosnian Jew and a Roma to the European Court of Human Rights claiming discrimination by the Bosnian state, which won a positive verdict in 2009. Ethnic discrimination in the workplace is common in Bosnia-Herzegovina (Amnesty International, 2006), as is segregation in education, where the problem of "two schools under one roof" remains unresolved despite millions of dollars in international aid which was spent to expunge this outrageous and antiquated practice. The ethnic dimension of social inequity, particularly in terms of constitutional rights and freedoms, protrudes in any discussion of social justice in the context of restoration of state/society relations and overcoming the legacy of war in Bosnia-Herzegovina and more broadly in the Western Balkans as a whole. This reflects certain myopia in the academic and policy debates, which overwhelmingly focus on the politics of Bosnia-Herzegovina's statehood, without sufficient appreciation that the politics of statehood are inseparable from its economic foundations (Connolly, 2013). Therefore, it is no surprise that there has been much less emphasis in this context on how the widespread informality that is endemic in the economic foundations of the local "elite bargain" struck against the disaccord over the future of the Bosnian state, operates as a parallel mechanism of exclusion which extends across discrimination and inequities associated with the primacy of the ethnic principle around which the state, society, and economy are organized.

Informality operates through a system of personalized relations. A survey of the Bosnian population reveals that personal connections are instrumental in accessing information, contacts, resources, and opportunities. In the UNDP (2009) poll as many as 95\% of the people surveyed reported that stela and veza - a colloquial shorthand for finding a fixer - was a decisive factor in gaining access to resources and opportunities, and only $10 \%$ of those interviewed believe that most people can be trusted. In this respect the patterns in Bosnia-Herzegovina resemble the patterns observed in a wider region, and particularly in Kosovo and FYR Macedonia, where the legacy of war and a weak economy combine to restrict the resource base, which, in turn, intensifies the scramble for a right access channel. Inequities in access to jobs, business opportunities and social welfare are a common experience and point of conversation across Bosnia-Herzegovina, and Kosovo and FYR Macedonia, too (B\&S, 2010; UNDP, 2011; ICG, 2002; Kostovicova, Martin \& Bojicic-Dzelilovic, 2012). Looking for a job without prior arrangement with an insider in the tight job market in Bosnia-Herzegovina is almost certain to end in failure and paying the mediator, particularly in the relatively safe, prestigious public sector jobs, is not uncommon. Reports in the local media frequently feature cases that illustrate privileged access to bank loans, particularly in the two majority state-owned banks in Bosnia-Herzegovina's two entities, granted to individuals close to elite groups, or who have privileged access to business contracts. Despite significant progress in 
business environment reforms that served to reduce the red tape, thereby narrowing opportunities for the abuse of rules and regulations, the system of bypassing the rules through personal connections holds firmly in place (Bojicic-Dzelilovic \& Kostovicova, 2013). This kind of arbitrary system is seen right down to the most commonplace of transactions, where access to credit backed by suspect collateral ${ }^{9}$ or securing preferred premises to start up a business (or access to healthcare, a secure place at the university and so on) is often mediated through personal channels and involves some sort of rule non-compliance. For anyone who has followed the intricacies of BosniaHerzegovina's most recent round of welfare system reform under the current stand-by agreement with the IMF, which has focused on overhauling and streamlining the bloated and non-transparent system of benefits to the war veteran population, an astounding portrait of a nation has appeared: ethnic fragmentation combined with personal connections, has created an army of false claimants milking the system (see for example: FBiH: Pravo na invalidnine izgubilo 929 korisnika, 2011). This is only one of many ways in which the state continues to be stripped and undermined through informal practices entrenched through the ethnic elites' rule. Devine and Mathisen (2005) aptly sum up Bosnia-Herzegovina's predicament in the following way:

Political parties control state assets, licencing, housing policy . . . appointments to public office and to management and executive functions of state owned companies, privatisation process, tax collection, public institutions, the security sectors etc. Still today, anyone wanting to move up the social or economic ladder within his or her ethnic group has to have support from one or more of political parties and the wider network that supports the status quo. Citizens use parallel structures to make things work and these parallel structures are often corrupt and criminal. (pp. 12-13)

These examples provide only a snapshot of some of the common forms of discrimination through informal arrangements involving disregard of rules and regulations observed in Bosnia-Herzegovina that allow privileged access to assets and resources. They serve to highlight that hidden privileges to those better connected are sometimes more impactful than any issues of ethnic lineage. According to Blundo and Sardan (2006), informality as a social mechanism of redistribution of resources and power that operates on a principle of privilege generates inequity and exclusion (p. 6). The findings of the UNDP research (2011) on social exclusion in the post-socialist countries of Europe and Central Asia suggest that in the Western Balkans, informal economy is less a social cushion and is more prone to criminality, corruption, and informal institutionalization thereby making the problems of poverty, inequality and social exclusion particularly troubling. Informal arrangements to access assets and resources operate through unequal relationships. As a consequence, inequality in the final line reproduces power relations in society (Bebbington, Dani, de Haan, \& Walton, 2008, p. 66) and thus allows the survival of Bosnia-Herzegovina's ethnic elites. 
The results of the Bosnian population survey quoted above and the subsequent discussion serve to point at the structural nature of informality and its societal acceptance as a feature of an inequitable post-war social order in which ethnic elites' interests are prioritized over general public interest. It is important to understand that in this kind of social order, which affords privilege to narrow groups, anyone can be excluded, regardless of the categories covered by the standard measures of social exclusion ${ }^{10}$ which occupy central place in the assessment of social cohesion, and by extension, post-war social reintegration The most recent social exclusion data on BosniaHerzegovina, which assess exclusion at the group level ${ }^{11}$, find that $33 \%$ of the population is at risk of poverty, and that exclusion is more concentrated in rural areas, among older age groups, and youth. Data on material deprivation show that over $70 \%$ of households appear to be unable to cover the unexpected expense of a certain magnitude, including life threatening events such as major illness in the family. Material deprivation is associated more with elderly, rural and less educated population (World Bank, 2012, pp. 23-27). In earlier surveys refugees and displaced people were reported as one of the groups most affected by social exclusion (UNDP, 2007). These group data on social exclusion disguise the issue that within each category, including that of displaced people, arguably among the most vulnerable of all, informality acts as an additional vector of differentiation with an ambiguous impact. It allows an individual's agency to change her/his predicament and to escape social exclusion (for this argument in a Kosovo case, see: Kostovicova, Martin, \& Bojicic-Dzelilovic, 2012). But simultaneously, because such problems may only be temporarily resolved, and because any resolution still stems from an innately unequal relationship, the outcome is what Wood and Gough (2006) call "adverse inclusion" in terms of long term well-being and equity. ${ }^{12}$ This method of resolving one's problems - and Wood and Gough focus on economic security - may involve coercive and exploitative relations and lead to dependence, which often result in long-term vulnerabilities. Societal acceptance of informality captures a disposition that suggests at least some of those caught in this inequitable web of social relations are unaware that the domination exists, which results in the perpetuation of informality (for similar arguments see: Bourdie as quoted in Meyer, p. 90).

How does inequality, as inscribed in the type of discriminatory practice described above, affect social reintegration in a post-war context? Informality cuts across various forms of formal institutional exclusion/inclusion of different groups and individuals, and, as stated before, it can lead to a kind of adverse societal incorporation that perpetuates vulnerabilities, reinforces unequal social relations, and erodes social cohesion. ${ }^{13}$ But there is also an additional important dimension as to how informality-related inequality impacts on social cohesion as the foundation upon which state/society relations are rebuilt. It is manifested through trust-inter-personal as well as institutional. Trust is vital in supporting socially just outcomes by rebuilding the implicit social contract amongst individuals and between citizens and the state. There is a strong view in much of the literature, particularly on informal 
economy and the role of social networks, that personal relations as an instrument in negotiating access to assets and resources are trust-enhancing (Meagher, 2010). Other scholars have asserted that sometimes personal relations mobilized to gain advantage in accessing information, resources, and services can be permeated by distrust and rivalry and can reinforce social inequality (Bourdie as quoted in Meyer, 2008). In post-war BosniaHerzegovina, where relations with the state involve resorting to informal networks and personal relations, the latter type of relations seems prominent. Thus, not only is institutional trust likely to be undermined, but the interpersonal trust too. Surveys of interpersonal and institutional trust repeatedly show that in Bosnia-Herzegovina, as indeed in most former communist countries, trust is low. The UNDP (2011) survey reveals an important finding in relation to trust; while people overall do not trust institutions, they often trust individuals who work in those institutions and help them "get things done" (UNDP, 2011, p. 31). This finding lends support to the claim of the prominence of socially destructive relations associated with pervasive informality inflicting Bosnia-Herzegovina society where reliance on informal arrangements in resolving everyday needs has become a norm. When the institutions in question concern access to goods and services to which individuals aspire, this dependence on informal arrangements as much as it is tacitly condoned, deepens the sense of injustice at an inter-personal level (p. 31). The same UNDP survey data reveal that trust in people, including those in close proximity, such as neighbours, along with trust in institutions is not only low, but has been weakening in the region. ${ }^{14}$ While the experience of war was being defined in the breaking of social ties at the work place, in the local community, even in many cases within ethnically mixed families, the post-war social order that reproduces structural inequality has contributed to deepen the mistrust. Vankovska, commenting on the Western Balkans (2007) claims: "in these countries, people live their separate lives in fear and distrust, unable to comprehend their common interest" (p. 273).

Trust, according to Mungiu-Pippidi (2011, p. 9), is an expectation based on experience. It is unlikely to develop when people believe that others have advantage, because equal opportunity, along with economic equality, lie at the foundation of trust (Rothstein \& Uslaner, 2005, pp. 42-47). Nor is it likely to strengthen in the presence of state institutions involved in rule-breaking and rule-evading, usually reported in the form of "systemic corruption" that allegedly plagues Bosnia-Herzegovina's dysfunctional institutions. It has been argued earlier that in the war in Bosnia-Herzegovina, the source of widespread informality was a social transformation due to the economic criminalization that shaped the post-war economy and its surrounding elite. Looking at a different country context, Kathleen Sexsmith $(2009$, p. 82) has shown that the type of wartime social transformation can have constructive or destructive impacts on post-war societal reintegration. In Bosnia-Herzegovina, widespread informality and its attendant inequality have created inequities, which are not easy to reverse. ${ }^{15}$ The consequences in terms of social justice and societal reintegration have been perilous. 


\section{Conclusion}

In this article, I have looked at the impact of informal practices including corruption and informal economy on social justice and societal reintegration in the aftermath of war, drawing on the examples from Bosnia-Herzegovina. Central to the argument the article makes is the reconceptualization of the notion of informality. To study the problems of widespread informal economy and corruption in post-war Bosnia-Herzegovina, I have proposed to apply the concept of "economic criminalization." It serves as a "conceptual pivot" which provides a framework to understand various forms of disregard for formal rule in the context undergoing fundamental change, in which according to Blundo and de Sardan (2006), "individual and collective relations to power and institutions are also changing" (p. 30). The double transition from communism and war in Bosnia-Herzegovina has created such a context in which the state is not clearly differentiated from other societal actors and engages in informal practices itself. This suggests that pervasive informality is structural feature of the country's post-war transition. Any war-affected country's transition to peace depends crucially on the nature of political settlement among its main elites, since without a shared vision over a country's future, it is impossible to generate the kind of dynamics necessary to deal with the legacy of war and to set a path to societal reconstruction. The nature of political settlement is fundamental because it defines how relations between the state and society are structured. In Bosnia-Herzegovina, the political settlement around the three-way ethnic division of the country, in which ethnic criteria permeate every aspect of life, shapes distribution of power and resources within society. The ethnic elites are the main protagonists in the informal practices which permeate Bosnia-Herzegovina body politics and economy and keep the country in a sort of protracted limbo preventing renegotiation of the political settlement which is necessary to break out of the deadlock.

It is important to understand that informality is not just, or primarily, an economic problem but its roots are also political, socio cultural, and psychological. Consequently, the effects are equally multifaceted. The mainstream explanations of informal economy and corruption fail to capture the intricate way in which politics and economics mix in BosniaHerzegovina's context, and the implications it has on the social legitimacy of rules. Therefore, they cannot account for the link between elite level informality and that involving ordinary citizens. The combination of the legacy of non-compliance with state-sanctioned rule, the pressures and constraints in dealing with and overcoming the legacy of war, and the opportunities that exist in the context of weak institutions all combine to make a resort to informal practice a way of how society operates.

Although exclusion along ethnic lines is institutionalized in BosniaHerzegovina, and captures the attention of the scholars studying the country's political economy, it is not the only axis along which exclusion 
and discrimination in fact happens. This analysis has demonstrated that informality, whose pervasive nature is attributed to the relation between the state and society in post-war Bosnia-Herzegovina, operates as another (hidden) mechanism of discrimination. It is not confined to a particular group or a category of individuals, but applies across the board. An important, and perhaps paradoxical, aspect is that although informality is anchored in inequitable social relations, it is nevertheless tolerated in everyday life. As we have shown in our other work (Kostovicova, Martin, \& Bojicic-Delilovic, 2012), an individual does not question that he/she has to look for a contact or even pay a bribe, but the frustration is how to find the right agent who could facilitate access to valued resources and opportunities. A backward loop from informality to inequitable social relations operates, reinforcing exclusion and marginalization. In this way, informality-related indirect discrimination in accessing valued resources, such as jobs, income generation opportunities, healthcare and so on, which is prominent in a depressed economic context of Bosnia-Herzegovina, easily translates in the popular perceptions into an ethnically-related discrimination (Vankovska, 2007). Thus the two dynamics, one a discrimination that stems out of an ethnified state, and the other an informal practice that permeates its institutions, interlock to undermine societal reintegration. The victim of this destructive spiral is trust, both interpersonal and generalized trust in state and its institutions. This makes "bottom up" pressure that would disturb the status quo and would make the democratic process difficult to develop. The absence of the credible counterforce to ethnic rule is also linked with the failure to deal with the legacy of war economy and its protagonists early into the post-war reconstruction phase. According to Cheng (2012), this has sent the signal to the population that "the rules of the post-war game have already been fixed," and has worked to sustain the power of ethnic elites.

Social justice is about equity and equality of opportunity, and these are distorted when informality, such as that manifested in post-war BosniaHerzegovina, is widespread, and equality of access is denied to individuals. This paper has drawn attention to the importance of understanding contextspecific drivers of exclusion and marginalization which undermine long term goals of societal reintegration as the cornerstone of post-war rehabilitation.

\section{Notes}

1 Kanbur argues, as have a number of scholars before him, that ultimately the nature of informal economy, and more broadly informality itself, depends on the aims of each particular research in question (Kuchta-Helbling, 2000).

2 There is a large literature that provides an overview of various definitions and debates on informal economy. An understanding of informal economy as unrecorded economic transactions that are not captured by the relevant statistics, commonly used in economics, illustrates definitional approach.

3 For a detailed discussion of these two broad traditions of studying informal economy, see: Kuchta-Helbling, 2000.

4 A case in point is recent important research on corruption outside fully developed 
liberal market democracies by Alina Mungiu Pippidi and her colleagues (MungiuPippidi, 2011). This, in many respects important research that aptly captures the conceptual traps and shortcomings in the mainstream literature on corruption, keeps informal economy at the margins of analysis, and does not address violent conflict at all.

5 The emergence of "violent entrepreneurs" is representative of this process.

6 In Bosnia-Herzegovina the two processes are conflated, which generates distinct dynamics worth noting when discussing informality. See: Donais, 2008.

7 According to the Office of High Representative, formal economy amounted to some $20 \%$ of Bosnia-Herzegovina output in 1995, while the rest was "gray" and "black" economy. Cited in USIP, 2002 p. 6.

8 According to Hesselbein, the profile of informal economy provides important insights in the nature of "elite bargain" as common understanding of the "rules of the game" by the elite at any given point in time (Hesselbein, 2001, p. 1).

9 The statistics on default consumer loans with Bosnia-Herzegovina commercial banks are illustrative in this respect.

10 Social exclusion discourse which focuses on formal rights and entitlements elides this type of inequality which is produced by social practice and insufficient enforcement of relevant regulation.

11 The UNDP Regional Human Development report, Beyond Transition: Towards Inclusive Societies breaks ground in its approach to social exclusion in that it departs from income-based measures of poverty and develops a methodology for quantifying a complex nature of social exclusion with a focus on an individual. (UNDP, 2011).

12 In Bosnia-Herzegovina, as indeed across the region, it is not uncommon for employees to enter into arrangements with employers whereby they are officially paid minimum wage supplemented by payment in cash so that the employer avoids paying social contributions.

13 On informal employment in Bosnia-Herzegovina, see: Krstic, G. and Sanfey, P., 2006.

14 The survey by Aasland, et al, 2012, which focuses on trust in informal practice among elites in Eastern Europe and the Western Balkans, confirms these findings.

15 Rothstein and Uslaner (2005) have argued that over time both (mis)trust and inequality are "sticky."

\section{References}

Aasland, A., Grodeland, A.B. \& Pleines, H. (2012). Trust and informal practice among elites in East Central Europe, South East Europe and the West Balkans. Europe-Asia Studies, 64(1), 115-143.

Amnesty International. (2006). Bosnia and Herzegovina behind closed gates: Ethnic discrimination in employment. London: Amnesty International.

Anastasijevic, D. (2010). Getting better? A map of organized crime in the Western Balkans. In Bendek et al (eds.), Transnational terrorism, organized crime and peace building: Human security in the Western Balkans (pp. 149-169). Houndmills, Basingstoke: Palgrave Macmillan.

Andreas, P. (2004). Criminalized legacies of war. Problems of Post-Communism, 52(3), 3-10.

Aslund, A. (1999). Post-communist Economic Transformation. In Braun, A. \& Barany, Z, (eds.), Dilemmas of transition: The Hungarian experience (pp. 69-88). Lanham-Boulder-New YorkLondon: Rowman \& Littlefield.

B\&S Europe. (2010). Survey on the extent and prevention of the illegal economy and money laundering in Kosovo, A report prepared for the European Agency for Reconstruction. Pristina: B\&S Europe.

Bebbington, A.J., Dani, A.A, de Haan, A \& Walton, M. (2008). Institutional pathways to equity: Addressing inequality traps. Washington: The World Bank.

Blundo, O. \& de Sardan (with Arifari, N.B. \& Alou, M.T.). (2006). Everyday corruption and the state: Citizens and public officials. London-New York: Zed Books 
Bojicic-Dzelilovic, V., \& Kostovicova, D. (2013). Private sector development in post-conflict Bosnia-Herzegovina. East European Politics, 29(1), 19-36.

Cheng, C. (2013). Private and public interests: Informal actors, informal influence, and economic order after war. In M. Berdal \& D. Zaum (Eds.), Political economy of peacebuilding: Power after peace (pp. 63-79). Abingdon: Routledge.

Connolly, R. (2013). The Economic sources of social order development in post-socialist Eastern Europe. Abingdon: Routledge.

De Soto, H. (2001) The mystery of capital: Why capitalism triumphs in the west and fails everywhere else. London: Black Swan.

Devine, V. \& Mathisen, H. (2005). Corruption in Bosnia and Herzegovina-2005: Options for Swedish development cooperation 2006-2010. Bergen: Chr. Michelsen Institute.

Divjak, B. \& Pugh, M. (2008). The political economy of corruption in Bosnia-Herzegovina. International Peacekeeping, 15(3), 373-386.

Donais, T. (2005). Political economy of peacebuilding in post-Dayton Bosnia. London and New York: Routledge.

Donais, T. (2003). The political economy of stalemate: Organized crime, corruption and economic deformation in post-Dayton Bosnia. Conflict, Security and Development, 3(33), 359-382.

European Stability Initiative. (1999). Reshaping international priorities in Bosnia and Herzegovina. Part 1: Bosnian power structures. Brussels: European Stability Initiative.

Feige, E., \& Ott, K. (1999). Underground economies in transition: Unrecorded activity, tax evasion, corruption and organized crime. Aldershot, Hants: Edgar Elgar.

FBiH: Pravo na invalidnine izgubilo 929 korisnika. (2011). Retrieved from http://www.vijesti. ba/vijesti/bih/54089-FBiH-Pravo-penzije-invalidnine-izgubilo-929-korisnika.html.

FREN. (2013). The shadow economy in Serbia: New findings and recommendations. Belgrade: Foundation for the Advancement of Economics.

Griffiths, H. (1999). A political economy of ethnic conflict, Ethno-nationalism and organized crime. Civil Wars, 2(2), 56-73.

Gross, D., \& Steinher, A. (2004). Economic transition in Central and Eastern Europe: Planting the seeds. Cambridge: Cambridge University Press.

Grzymala-Busse, A.G. (2010). The best laid plans: The impact of formal institutions in transitional regimes. Studies in Comparative International Development, 45, 311-332.

Guha-Khasnobis, B., Kanbur, R. \& Ostrom, E., (Eds.). (2006). Linking the formal and informal economy: Concepts and policies. Oxford: Oxford University Press.

Haas, L. (2011). How to formalise the informal? The dynamics of the grey economy in the Western Balkan region: The case of Kosovo. Berlin: Hertie School of Government.

Helmke, G. \& Levitsky, S. (2004). Informal institutions and comparative politics: A research agenda. Perspectives on Politics, 2(4), 725-740.

Hellman, J.S., Jones, G. \& Kaufman, D. (2000). “Seize the state, seize the day”: State capture, corruption, and influence in transition. Washington: World Bank Institute.

Henry, S. \& Sills, S. (2006). Informal economic activity: Early thinking, conceptual shifts, continuing patterns and persistent issues - a Michigan study. Crime, Law and Social Change, 45(4-5), 263-28.

Hesselbein, G. (2011). Patterns of resource mobilisation and the underlying elite bargain: Drivers of state stability or state fragility? London: London School of Economics and Political Science.

International Crisis Group. (2002). Macedonia's public secret: How corruption drags the country down. Skopje/ Brussels: ICG Balkan Report 133.

International Labour Organisation. (2011). A comparative overview of informal employment in Albania, Bosnia and Herzegovina, Moldova and Montenegro. Budapest: International Labour Organization.

Johnson, F.E., Kaufmann, S. \& Zoido-Lobaton, D. (2000). Dodging the grabbing hand: The determinants of unofficial activity in 69 countries. Journal of Public Economics, 76, 456-493.

Kanbur, R. (2009). Conceptualizing informality: Regulation and enforcement. Indian Journal of Labour Economics, 52(1), 323-342.

Kostovicova, D., Martin, M. \& Bojicic-Dzelilovic, V. (2012). The missing link in human security research: Dialogue and insecurity in Kosovo. Security Dialogue, 43(6), 569-585.

Krstic, G. \& Sanfey, P. (2007). Mobility, poverty and wellbeing among informally employed in 
Bosnia-Herzegovina. Economic Systems, 31(3), 311-335.

Kuchta-Helbling, K. (2000) Barriers to participation: The informal sector in emerging democracies. Sao Paolo: Centre for International Private Enterprise. Retrieved from www.cipe/org/sites/default/files/publication-docs/informalEnglish.pdf

Ledeneva, A. (2006). How Russia really works: The informal practices that shaped post-Soviet politics and business. Ithaca, NY: Cornell University Press

Lindeman, S. (2008). Do inclusive elite bargains matter? London: London School of Economics and Political Science.

Matkovic, G. (2006). Overview of poverty and social exclusion in the Western Balkans Stanovnistvo, 44, 7-46.

Meagher, K. (2010). Identity economics: Social networks and the informal economy in Nigeria. Woodbridge, England: James Currey.

Meyer, G. (Ed.). (2008). Formal institutions and informal politics in Central and Eastern Europe. Opladen Farmington Hills: Barbara Budrich Publishers.

Mungiu-Pippidi, A. (2011). Contextual choices in fighting corruption: Lessons learned. Oslo: NORAD.

Nadin, S. \& Williams, C.C. (2012). Blurring the formal/informal economy divide: Beyond dual economies approach. Journal of Economy and its Application, 2(2), 1-19

Newman, E. with Keller, N. (2007). Criminal legacies of war economies. Journal of Peacebuilding and Development, 3(3), 49-62.

ODI. (2012). Report on development, fragility and human rights. London: ODI.

Preston-Whyte, E. \& Rogerson, C. (Eds.). (1991). South Africa's informal economy. Cape Town: Oxford University Press.

Pugh, M. (2004). Rubbing salt into war wounds: Shadow economies and peacebuilding in Bosnia and Kosovo. Problems of Post-Communism, 52(3), 53-60.

Putzel, J \& DiJohn, J. (2012). Meeting the challenges of crisis states. London: London School of Economics and Political Science.

Raiser, M. (1997). Informal institutions, social capital and economic transition: Reflection on a neglected dimension. London: EBRD.

Rothstein, B. \& Uslaner, E.M. (2006). All for one: Equality, corruption, and social trust. World Politics, 58(1), 41-72.

Ruggeri Laderchi, C. \& Savastano, S. (2013). Poverty and exclusion in the Western Balkans: New directions in measurement and policy. New York-Heidelberg-Dordrecht-London: Springer.

Sapir, J. (2006). Shadow economy and economic criminalization in transition economies. In B. Coriat, P. Petit, \& G. Schmeder (Eds.), The hardship of nations: Exploring the paths of modern capitalism (pp. 267-291). Cheltenham: Elgar Edgar.

Schneider, F. (2006). Shadow economies around the world: What do we really know? Bonn: IZA.

Sexsmith, K. (2009). Violent conflict and social transformation: An institutionalist approach to the role of informal economic networks. European Journal of Development Research, 21(1), 81-94.

Simon, J., Kaufman, D. \& Shleifer, A. (1997). The unofficial economy in transition. Brookings Papers on Economic Activity, 2, 159-239.

Staniland, P. (2012). States, insurgents, and wartime political orders. Perspectives on Politics, $10(2), 243-264$

Stefes, C. (2006). Understanding post-society transitions: Corruption, collusion and clientelism. Houndmills: Palgrave Macmillan.

Stubbs, P. (2009). Social protection and social inclusion in the Western Balkans: A synthesis report. European Commission.

Tomas, R. (2009). Gray economy in Bosnia and Herzegovina. Banja Luka: Friedrich Ebert Stiftung.

Transparency International. (2012). Corruption perception index. Retrieved from http://www. transparency.org/cpi2012/results

UNDP. (2007). Social inclusion: Bosnia-Herzegovina national human development report. Sarajevo: United Nations Development Program.

UNDP. (2009). The ties that bind: Social capital in Bosnia and Herzegovina. Sarajevo: United Nations Development Program.

UNDP. (2011). Beyond transition: Towards inclusive societies. Regional Human Development 
Report. Bratislava: United Nations Development Program.

UNODOC. (2008). Crime and its impact on the Balkans and affected countries. Vienna: United Nations Office on Drugs and Crime.

United States Institute for Peace. (2002). Lawless rule versus rule of law in the Balkans. Washington: United States Institute for Peace.

Upchurch, M. (2012). Persistent economic divergence and institutional dysfunction in postcommunist economies: An alternative synthesis. Competition and Change, 16(2), 112-129.

Vankovska, B. (2007). The human security doctrine for Europe: A view for below. International Peacekeeping, 14(2), 264-281.

Wood, G. \& Gough, I. (2006). A comparative welfare regime approach to global social policy. World Development, 34(20), 1696-1712.

Woodward, S. (2011). State-building for peace-building. What theory and whose role? In R. Kozul-Wright \& P. Fortunato (Eds.), Securing peace: State-building and economic development in post-conflict countries (pp.87-113). New York: Bloomsbury Academic.

World Bank. (2011). Conflict, security and eevelopment. Washington: The World Bank.

World Bank. (2012). Social exclusion in Bosnia and Herzegovina and the global crisis. Washington: The World Bank.

World Bank (2007). Informality, exit and exclusion. Washington: The World Bank. 